\title{
CONDITIONS OF THE OCCURRENCE OF ANEMONE SYLVESTRIS IN A KETTLE HOLE IN NORTH-EASTERN POLAND
}

\author{
ANNA JUSTYNA KWIATKOWSKA-FALIŃSKA, JANUSZ BOGDAN FALIŃSKI \\ Faculty of Biology \\ Białowieża Geobotanical Station of Warsaw University \\ Sportowa 19, 17-230 Białowieża, Poland \\ e-mail: sekretariat.bsg@uw.edu.pl
}

(Received: March 13, 2006. Accepted: January 4, 2007)

\begin{abstract}
The research, in 2004, was focused on the whole population of Anemone sylvestris (Snowdrop Windflower) present in the area of a kettle hole $\left(0.8 \mathrm{~km}^{2}\right)$ in north-eastern Poland $\left(52^{\circ} 50^{\prime} 00^{\prime}\right.$ 'N; $\left.23^{\circ} 11^{\prime} 20^{\prime \prime} \mathrm{E}\right)$. The location of 56 clumps of generative specimens was surveyed. They numbered from several to approx. 1500 specimens. The number of generative specimens in this population exceeded 10000 . On account of this, it is a unique stand of $A$. sylvestris in Poland.

The relationship between the occurrence of the Snowdrop Windflower and the presence of kame hills and ridges has been proven. Low slopes of kame with an inclination of $10-20^{\circ}$, and a north-eastern or eastern exposition has been found as the local ecological optimum for this species.

Research carried out in 1970-2001 on 5 permanent plots ( $25 \mathrm{~m}^{2}$ each) has shown that: 1) Anemone sylvestris is an essential element of xerothermic grasslands of the order Festucetalia valesiacae; 2) the species suddenly withdraws from the parts of land on which woody species have already reached the shrub layer; 3) the greatest danger for the population of $A$. sylvestris in this area is the process of secondary succession initiated by the discontinuation of grazing on the kame hills.
\end{abstract}

KEY WORDS: Anemone sylvestris, kame forms, xerothermic grassland, secondary succession.

\section{INTRODUCTION}

\section{Research area}

The research was carried out in north-eastern Poland, in the vicinity of the village of Haćki, situated on Równina Bielska (Bielska Plain). The area is surrounded by Drohicka, Wysokomazowiecka, and Białostocka High Plains. The flat and slightly rolling landscape of the plain is diversified by the presence of moraine and kame hills. Exceptionally numerous concentrations of these hills occur in the vicinity of Haćki (52`50'N; 2311'20'E). Kame hills occur there in a kettle hole occupying an area of $0.8 \mathrm{~km}^{2}$. The kettle hole is surrounded by a post-glacial kame plateau $166.5 \mathrm{~m}$ above sea level. The kettle hole, situated at $130-140 \mathrm{~m}$, is limited by steep slopes over 12 metres high. At the bottom of the kettle hole five kame hills and five kame ridges are found (Kondratiuk 1995; Kmieciak 2001; Brud 2001; Brud and Kupryjanowicz 2002; Ber 2005).

The area of each individual kame hill does not exceed $0.1 \mathrm{~km}^{2}$, and their height -12 metres. The hills have a circular base and are characterized by the high inclination of their slopes. They are a very characteristic feature of this area's landscape, and are compared to loaves of bread ( $\mathrm{Fa}-$ liński et al. 2005).
Kame ridges are deposits of an elongated shape, with steep slopes and a greater area (up to $0.3 \mathrm{~km}^{2}$ ) than kame hills. They differ considerably from one another with respect to length (from $160 \mathrm{~m}$ to $500 \mathrm{~m}$ ), but have a similar height (under $12 \mathrm{~m}$ ).

Kames, both ridges and hills, are built from fine-grained fluvioglacial deposits, many meters thick (Mojski and Nowicki 1961, 1964; Ber et al. 1964; Brud 2001; Kmieciak 2001; Ber 2005). On the base of these quaternary deposits white marly limestone is found (Olszewska and JugowiecNazarkiewicz 2000).

Kame hills and ridges in north-eastern Poland are especially valuable from a geo-botanical point of view, as they are a habitat similar to the steppe xerothermic grasslands, and a place of the occurrence of the Snowdrop Windflower Anemone sylvestris (Faliński 1972; Kwiatkowska-Falińska and Faliński 2005a-c).

\section{Object of research}

The Snowdrop Windflower is a species of Eurosiberian range occurring in middle and southern Europe, The Caucasus, Siberia, Anatolia and the Middle East (Piękoś-Mirkowa and Mirek 2003). In Poland this is a rare, protected species. Most often it is found on the Małopolska and Lubelska 
Uplands, by the lower Odra River, and in the Mazurian Lake District (Zając and Zając 2001). On the Polish lowland this species occurs in dispersed stands. According to PiękośMirkowa and Mirek, (2003), the individual populations of Anemone sylvestris in Poland are most often of low quantity (from several to a few dozen specimens). Patches constituted by hundreds of specimens are found very rarely.

Anemone sylvestris, as the only anemone occurring in Poland, is a hemicryptophytic and anemochoric species. It blooms in May and June and is pollinated by insects of different taxonomical classes.

With respect to habitat requirements, this is a heliophilous and thermophilous species, but is tolerant of partial shading. It is found most often on fresh, alkaline soils, in habitats containing carbonates in the base layer.

According to Matuszkiewicz (2001), the Snowdrop Windflower is a characteristic species of the community Geranio-Anemonetum sylvestris from the class Trifolio-Geranietea. The community is known in western Germany, and is considered there as a continental component of the vegetation. This community in Poland is poorly studied. Very small stands have been recorded in western Wielkopolska (Matuszkiewicz 2001).

On kame hills in Haćki Anemone sylvestris occurs in different species combinations, resulting from the transformation of xerothermic grasslands after the discontinuation of grazing (Kwiatkowska-Falińska and Faliński 2005a, b). In this area the Snowdrop Windflower is a component of both thermophilous xerothermic grasslands from the class $\mathrm{Fe}-$ stuco-Brometea, and also grasslands predominated by different meadow grasses (Dactylis glomerata, Festuca pratensis, F. rubrics, Phleum pratense, Poa pratensis), gras- slands predominated by Calamagrostis epigejos, and in ecotone vegetation of young woods under formation (photographic records - Faliński 2004).

From the 1960s the population of Anemone sylvestris in Haćki has been characterized by exceptional abundance, and numerous stands related to kame hills and ridges present in this region (Fig. 1).

The purpose of this work was: 1) estimation of the size of the Anemone sylvestris population present in the vicinity of Haćki; 2) ascertation of the relationship between the occurrence of this species and exposition, as well as the inclination of kame slopes occurring in this area; 3 ) determination of the function of this species in the process of the secondary succession of xerothermic grasslands after the discontinuation of grazing.

The work was prepared after the death of Professor Janusz Faliński, based on his unpublished materials. Owing to this, its results could not, unfortunately, have been shared with him.

\section{METHODS}

In 1969, on the biggest kame hill, 5 permanent investigative areas, $5 \times 5 \mathrm{~m}$ were established. Species listing, estimation of their quantity (with the Braun-Blanquet method), and photographic records of the area were performed in 1970, 1980, 1990, 1995 and 2001.

In 2004, over the whole area of the kettle hole in the Haćki region, the locations of all physiognomically distinctive clumps ("stands") of generative specimens of Anemone sylvestris were charted. Each clump was described by its

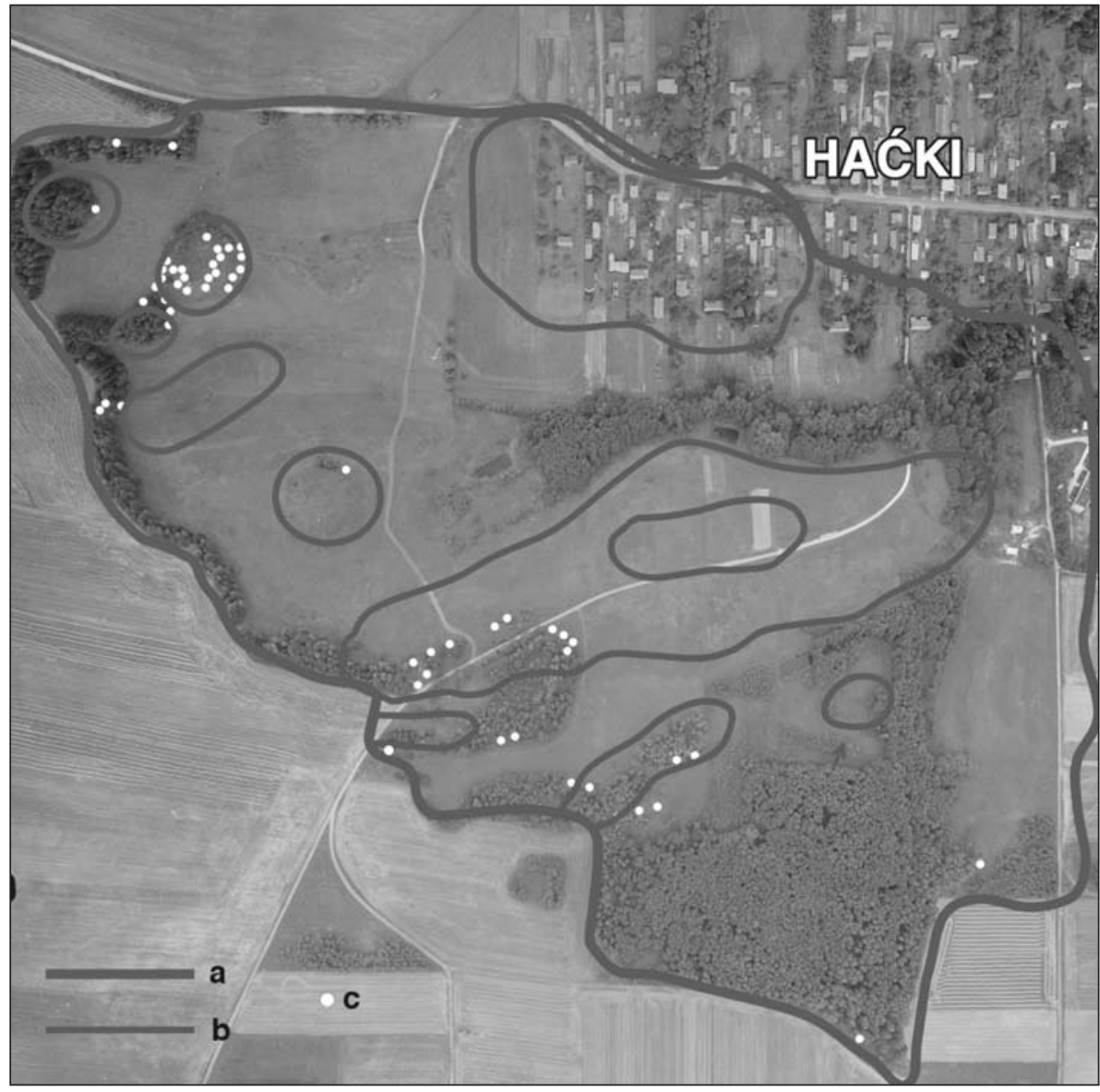

Fig. 1. The distribution of Anemone sylvestris clumps in the kettle hole in the vicinity of Haćki: a - edge of the kettle hole; b - borders of crevasses and basins in dead ice; $c-$ clump of generative specimens. 
position in relation to compass quadrants, the inclination of the slope, and the number of specimens occurring in a clump.

\section{RESULTS}

The occurrence of the population Anemone sylvestris in the area of the kettle hole in the region of Haćki is, remarkably, not random (Fig. 1).

Charted "stands" are connected with the borders of the former crevasses and basins created in dead ice during the last glaciation). Their locations in the landscape are at the present time occupied by kame hills and ridges characterised by relatively steep slopes.

Numerous "stands" of the Snowdrop Windflower are concentrated in the south-western part of the kettle hole (Fig. 1). In 2004, 56 physiognomically distinctive clumps were recorded in this area, numbering from several to about 1500 specimens. It is worth emphasizing that the entire population of this species totalled over 10000 generative specimens that year.

The distribution of specimen clumps of the anemone on each kame hill and ridge is dependent on the exposition of the slopes. Clumps of plants occur considerably more seldom on the slopes of north-western, western and south-western exposition. From among 56 clumps found, in such positions only 10 were recorded. The remaining 46 clumps were recorded on the slopes of hills of north-eastern, eastern and south-eastern exposition (Fig. 2). The vast majority of clumps (52) were recorded on relatively gently slanting slopes $\left(10^{\circ}\right.$ to $\left.30^{\circ}\right)$. Only 4 clumps were found on the most steepest slopes (over $30^{\circ}$ to $50^{\circ}$ ).

It was ascertained by analysing the number of specimens occurring in a clump that the majority of all large clumps (numbering from 200 to 500 specimens) were recorded on gently slanting slopes with a north-eastern exposition (Fig. 2). In total, on the slopes with north-eastern and eastern expositions, as much as $2 / 3$ of specimens of the local Anemone sylvestris population occurs (Table 1).

The analysis of the angle of all slopes occurring in the investigated area allowed the conclusion that on gentle slopes $\left(10^{\circ}\right.$ to $\left.20^{\circ}\right)$ about $60 \%$ of all found anemone specimens occurred.

Taking into account both these factors together (the exposition and the slope angle) the local ecological optimum for this species can be determined. In the region of Haćki the optimal conditions for the Snowdrop Windflo-

TABLE 1. The percentage of specimens in the population of the Snowdrop Windflower Anemone sylvestris occurring on slopes of the kame hill with respect to the inclination and exposition.

\begin{tabular}{|c|c|c|c|c|c|}
\hline \multirow{2}{*}{ Exposure } & \multicolumn{5}{|c|}{ Incline } \\
\hline & $10^{\circ}$ & $20^{\circ}$ & $30^{\circ}$ & $40-50^{\circ}$ & $\Sigma$ \\
\hline NE, E & 11.2 & 38.1 & 13.4 & 3.4 & 66.1 \\
\hline SE, S & 1.0 & 14.6 & 7.0 & 0 & 22.6 \\
\hline SW, W & 0.2 & 2.4 & 0 & 4.2 & 6.8 \\
\hline $\mathrm{NW}, \mathrm{N}$ & 0 & 4.4 & 0 & 0 & 4.4 \\
\hline$\Sigma$ & 12.4 & 59.5 & 20.4 & 7.6 & 100.0 \\
\hline
\end{tabular}

a

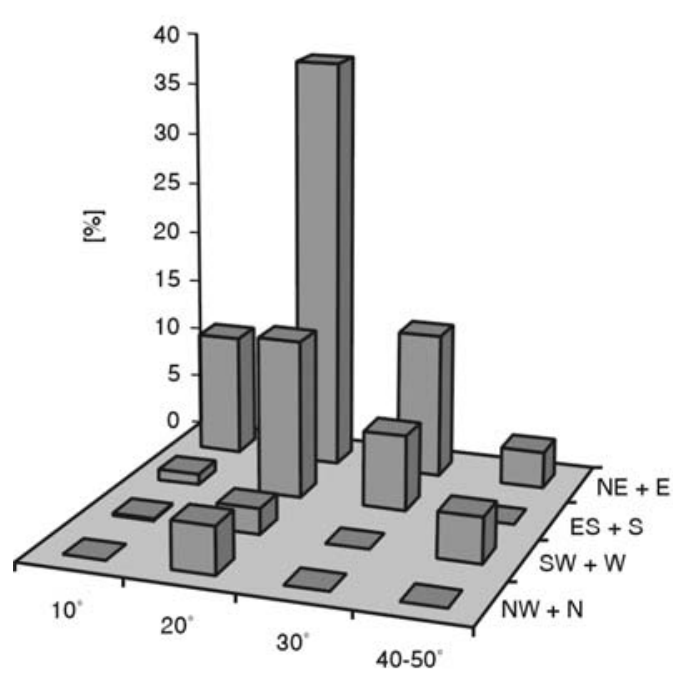

b

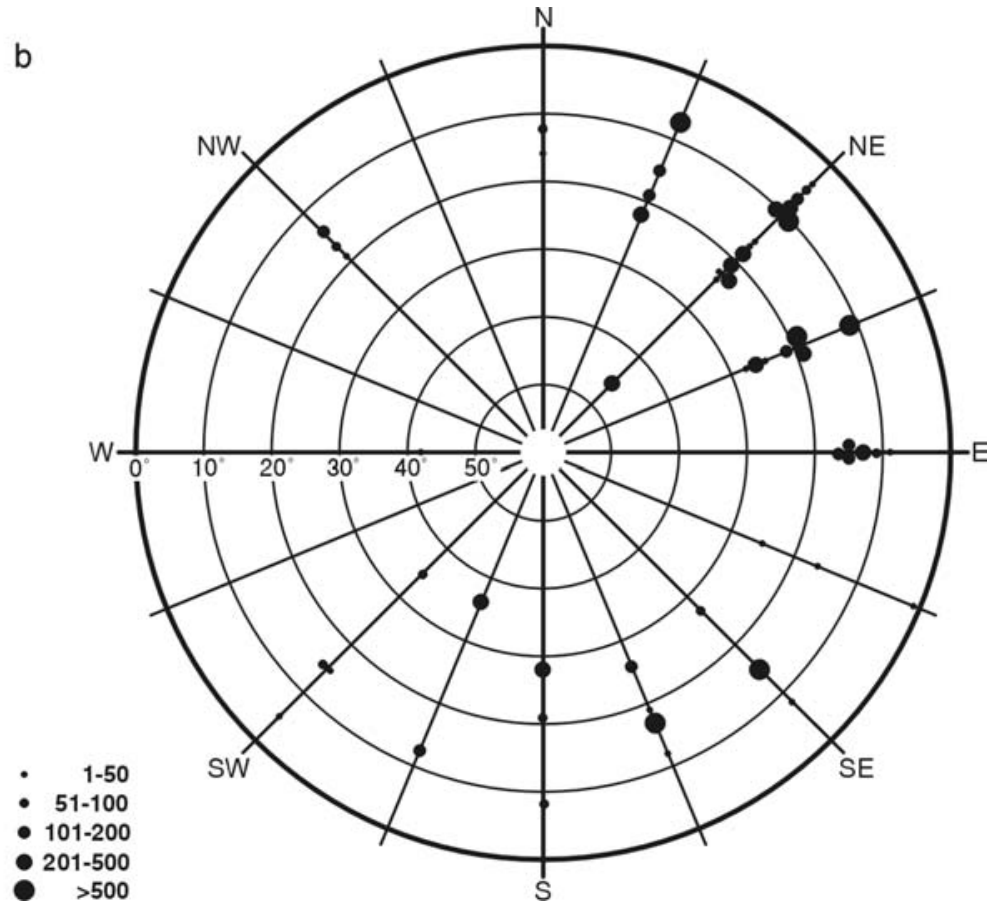

Fig. 2. a) percentage of specimens of Anemone sylvestris present on slopes of the kame hills with defined exposures and inclines; b) number of specimens of Anemone sylvestris in concentration and location of concentration with respect to slope exposure and inclination on the kame hills in Haćki. 
TABLE 2. Changes in the combination of species during the process of secondary succession on xerothermic grasslands.

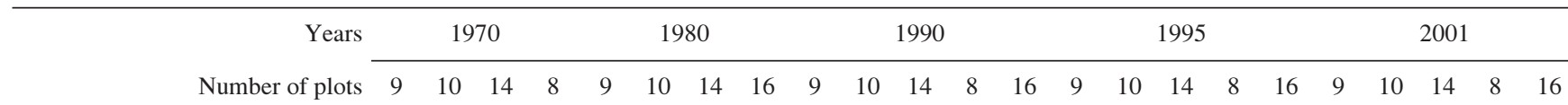

Species

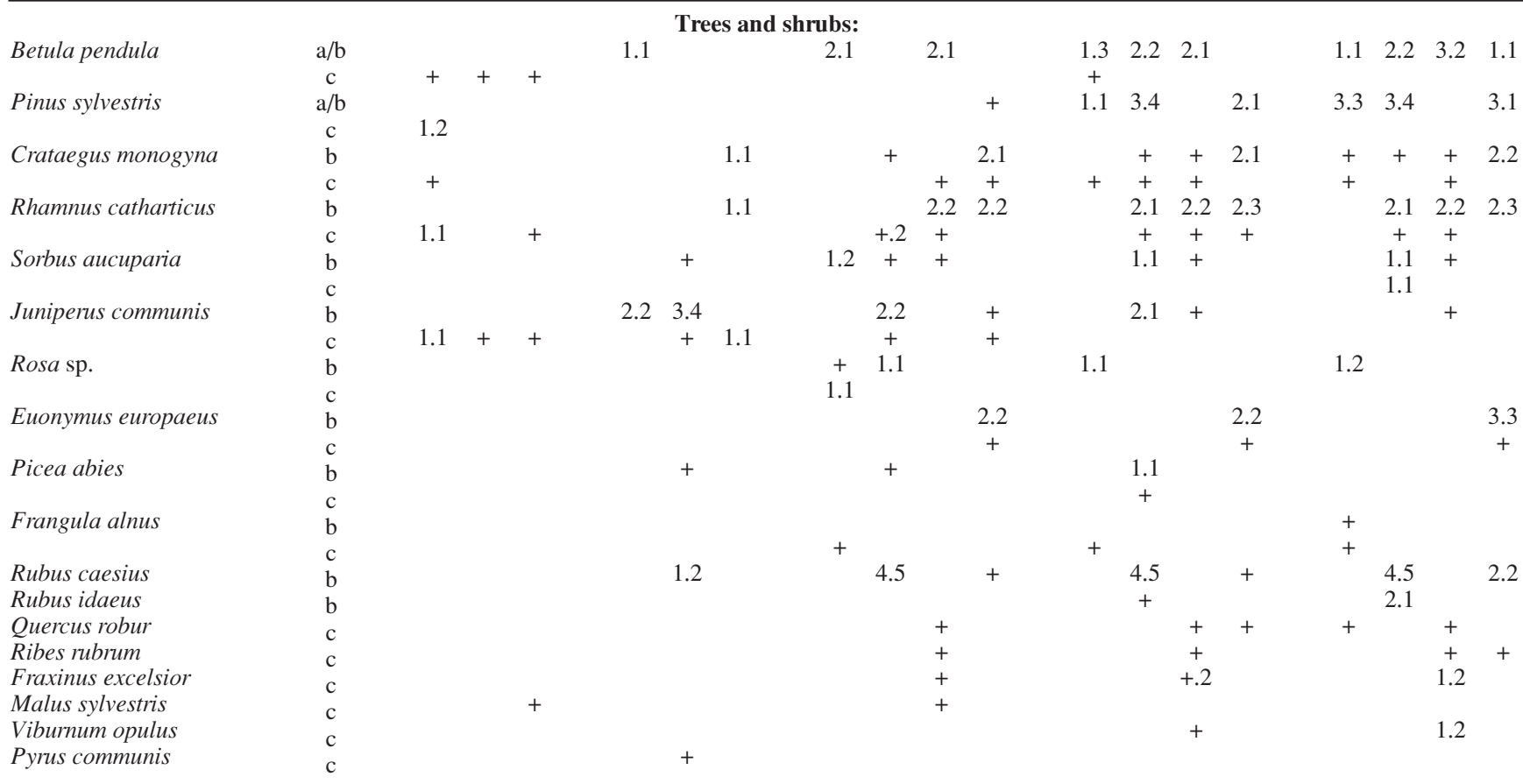

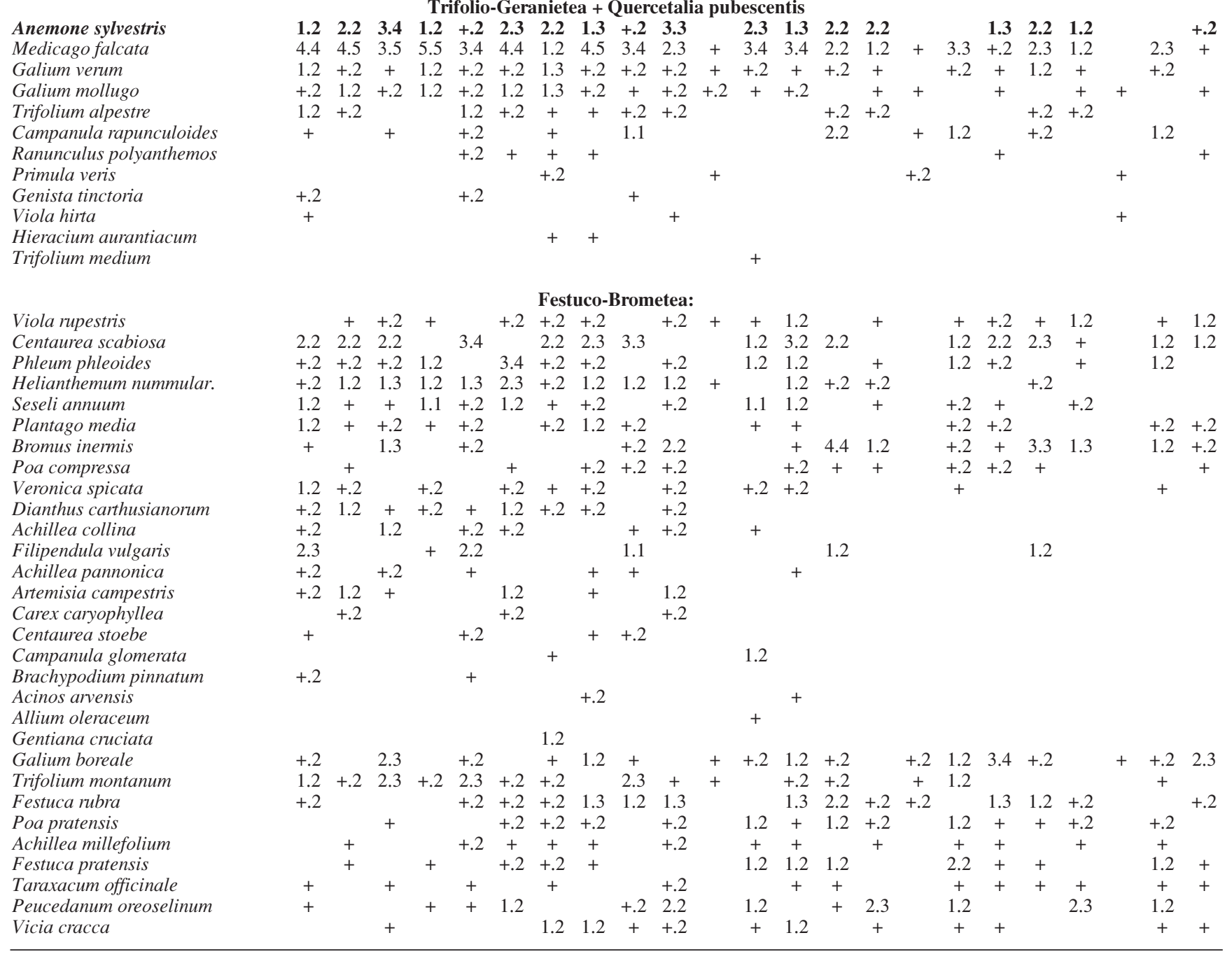


TABLE 2. Cont.

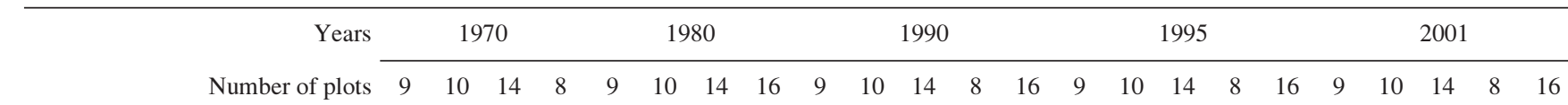

Species

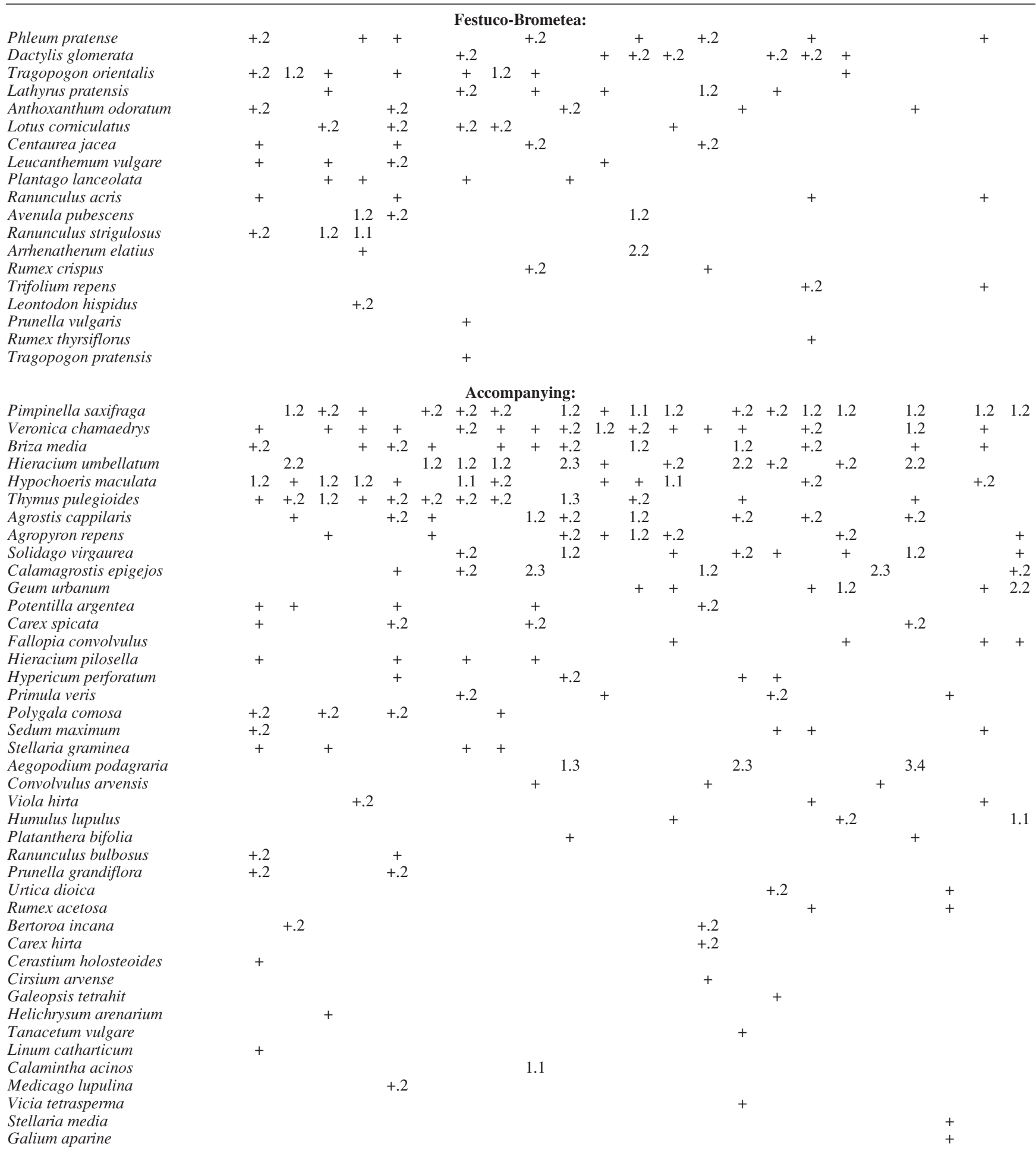

Bryophytes:

Camptothecium lutescens

Thuidium abietinum

Thuidium philiberti

Brachythecium albicans

Bryum caespiticum

Ceratodon purpureus

Mnium marginatum

Pleurozium schreberi

Rhytidiadelphus squarrosus

$$
\begin{array}{llll}
1.3 & 1.2 & 1.3 & +.2 \\
1.3 & +.2 & 1.3 & \\
& & +.2 & +.2 \\
& & & \\
& & & \\
& +.2 & & \\
& & &
\end{array}
$$


wer specimens are found in xerothermic grasslands situated on gentle slopes of kame areas with north-eastern and eastern expositions.

At the beginning of the research (1970) the plant cover for Anemone sylvestris ranged from 5 to $40 \%$ on each plot. Woody species occurred only in the herb layer (Table 2). After only 10 years on some plots $(10,14,16)$ specimens of woody species had already grown over the herb layer, creating a shrub layer. Juniperus communis (up to 40\%) and Crataegus monogyna (up to 20\%) had the greatest participation in the shrub-stocking. Plot 14 distinguished itself with the abundant occurrence of Rubus caesius (20\%) of which shrub-stocking attained over 50\% in 1990, 1995, and 2001.

In 1990 only plot 9 remained un-shaded by trees and shrubs. In this part of the patch such a situation remained to the end of the research. On all remaining plots $(8,10,14$, 16 ), in the following years of research the number of species and the number of woody species increased. Their specimens are already present in the tree and shrub layers (Table 2, Fig. 3). After 1990 the stocking of this layer reached as much as $70 \%$. Since then, the major part of the plots' surface has become shaded.

The uneven speed of inhabitation of different parts of the grassland by the seedlings of woody species, and the different speeds of their recruitment to the layer of shrubs meant that the xerothermic grassland (from the class FestucoBrometea, order Festucetalia valesiacae) remained on only one (9) plot (Table 2). However, within the time elapsed, the floristic abundance on this plot also decreased significantly.

The decrease of floristic abundance and the change in the combination of species observed on all plots are evidence of the initiation of the process of secondary succession. The first (1980) slight increase in the number of species from the classes Festuco-Brometea and Trifolio-Geranietea, and the invasion of seedlings of woody species onto the patch is an undoubted result of the discontinuation of grazing in the 1970s. This factor is also responsible for the initiation of the process of secondary succession. The species from the class Festuco-Brometea are deleted from the grassland most quickly (Table 2, Fig. 3). In addition, a sudden deletion from the patch of the meadow-species Molinio-Arrhenatheretea is observed. Such a process significantly accelerated in the period 1980-2001. The recruitment of woody species into the layer of shrubs and trees occurred at the same time.

On the grounds of mean data for 5 plots, it can be stated that the population of Anemone sylvestris "behaves" similarly to other species from the class Trifolio-Geranietea. During the process of secondary succession the Snowdrop Windflower gradually withdraws from the investigated areas (Fig. 3 mean).

However, it is necessary to underline when analysing the situation on each plot that the decrease in cover of this species can be a very violent process until its entire elimination from the part of the patch (plots 8,14 ). The deletion of the anemone from the patch is combined with the recruitment of several species to the layer of trees and shrubs (Fig. 3).

An increase in the covering of Anemone sylvestris was observed in the researched period on only one plot (9). At the same time, in spite of the absence of woody species in the layer of trees or shrubs, the number of species from all specified ecological groups decreased, and the Snowdrop Windflower filled in the left gaps.

\section{DISCUSSION}

As already emphasized at the beginning of the work, each stand of Anemone sylvestris in Poland is very sparsely populated (Piękoś-Mirkowa and Mirek 2003). The local population of the Snowdrop Windflower from the Haćki region is unique in this respect, as it numbers over 10000 generative specimens. Such a numerous population, with a high participation of specimens in a generative phase, occurring in diversified habitats (with respect to the exposition and the slope inclination) probably represents the full genetic diversity of this species. It is also exceptionally valuable on that account. It cannot be guaranteed in other stands on the Polish lowland, which are dispersed at great distances from each other, (Zając and Zając 2001). It is very likely that they represent only a part of the genetic diversity of Anemone sylvestris.

It stands to reason that over a longer time perspective the specific protection in situ may be not effective unless it guarantees the maintenance of the whole genetic variability of the species which is under protection. For this reason the lowland stand of Anemone sylvestris in Haćki should be protected in the whole area of the kettle hole.

Besides the abundance, the exceptional rank of the stand in Haćki also results from the affiliation of Anemone sylvestris to the slopes of kame forms present in this area. From among other land forms the slopes of the kettle hole, kame hills and ridges are a habitat of this species. As proved, the highest number of specimens survive and develop on relatively gentle slopes of north-eastern exposition. Unfortunately, as other research showed (Kwiatkowska-Falińska and Faliński 2005) this part of the slopes is most quickly entered by trees and shrubs. The survival of the local population of the Snowdrop Windflower in this area depends on immediate action focused on active protection, and assigning the area of the kettle hole for reserved protection. Establishing a natural reserve has already been postulated by Ber (2005), Kwiatkowska-Falińska and Faliński (2005) and Kobyliński and Szymański (2005). Owing to the additional value of this area (geological, geobotanical and archaeological) the authors have introduced a project for establishing a complex natural-archaeological reserve (Ber et al. 2005).

The present work also results in specific conclusions concerning the methods of active protection. Unfortunately, present methods of landscape use, without active protective intervention, indicate that the fate of xerothermic grasslands, and with them the Snowdrop Windflower, is a foregone conclusion. Formerly, some types of anthropopressure on the vegetation covering of the kame hills in Haćki, including forest felling and cattle grazing, were favourable for the creation and further persistence of xerothermic grasslands. At the present time such types of influence are already forgotten. Conversely, the factors initiated by man which threaten the survival of the xerothermic grasses and the affiliated population of the Snowdrop Windflower, have become more intense. The most dangerous factor is the process of secondary succession initiated 

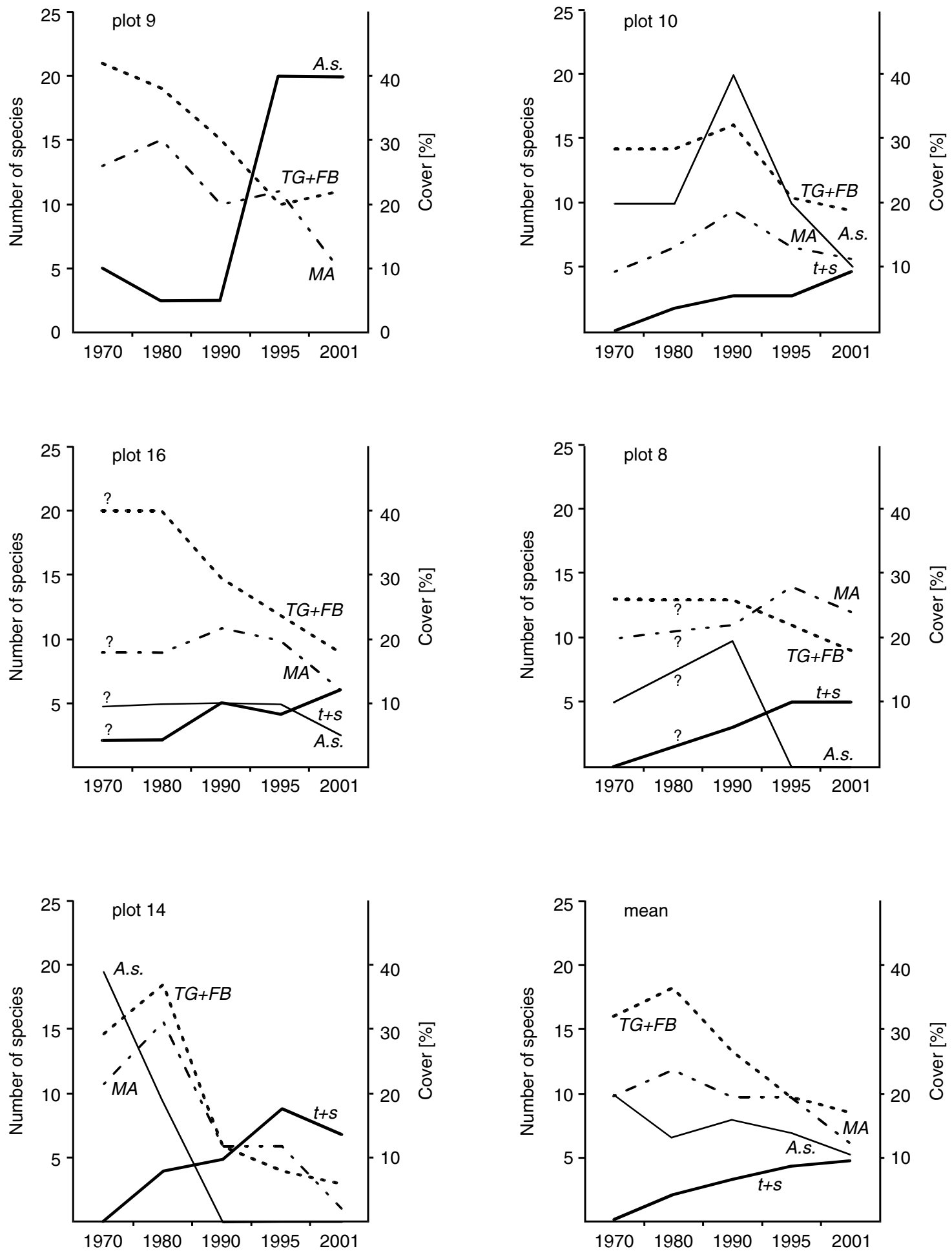

Fig. 3. Changes in Anemone sylvestris covering and the number of species from classes Festuco-Brometea (FB), Trifolio-Geranietea (TG), Molinio-Arrhenatheretea (MA) and woody $(\mathrm{t}+\mathrm{s})$ species in the layer of trees and shrubs.

by the discontinuation of grazing (Kwiatkowska-Falińska and Faliński 2005a, b). As shown in the presented research, Anemone sylvestris is deleted from the areas strongly shaded by trees and shrubs. Although the specimens are able to survive for some time (even abundantly blooming and bearing fruit) in the ecotone vegetation of young woods, they inevitably become extinct because of the continuous expansion of trees into the grassland habitat.

As proved in the present work Anemone sylvestris is not in a position to survive in the areas being covered by shrubs (Rubus caesius, Rhamnus cathartica or Crataegus monogyna) or trees (Betula pendula, Sorbus aucuparia and Pinus sylvestris).

However, the maintenance in the landscape of these exceptionally beautiful white fields, abundantly flourishing in late spring, demands not only the elimination of trees and shrubs. To prevent the renewed overgrowing of slopes it is necessary to reintroduce intensive grazing. For the natural grass formations including steppes, to which the xerothermic grasslands are linked, the presence of large herds 
of herbivores is characteristic. In the investigated case their function will be best covered by the herbivores with trees and shrubs in their diet. Among domestic animals sheep are such herbivores. Due to the landscape, tourist value, and the resistance of animals to the weather conditions, such herbivores could also be Tarpan horses.

Similar, though less intensive, forms of active protection demand the restoration to the landscape of Białowieża Forest of the community of thermophilous oak forest Potentillo albae-Quercetum (Kwiatkowska-Falińska, in press). According to the results of many years' research (Kwiatkowska 1972, 1986, 1993, 1994, 1996; Kwiatkowska et al. 1997) the reason for their recession is the change of intensity and direction of dominant herbivorous pressure. As a result of the above-mentioned, the maintenance of the biodiversity of this region requires urgent active protection of the floristically richest communities, both woody (Potentillo albae-Quercetum) and non-woody (grasslands from the order Festucetalia valesiacae).

\section{ACKNOWLEDGEMENTS}

Heartfelt thanks to the reviewer of this work, whose clear-sighted remarks helped very much in writing the presented version of the article. I also thank the staff of the Białowieża Geobotanical Station, without whose kindness and help this work could not have been completed.

\section{LITERATURE CITED}

BER A. 2005. Warunki geologiczne i geomorfologiczne powstania zespołu kemów w Haćkach. In: Haćki. Zespół przyrodniczo-archeologiczny na Równinie Bielskiej. Faliński J.B. et al. (eds). Wyd. Białowieska Stacja Geobotaniczna UW. pp. 9-29. (in Polish)

BER A., MAKSIAK S., NOWICKI A.J. 1964. Z zagadnień geologii czwartorzędu dorzecza górnej Narwi. Przegl. Geol. 12 (141): 473-476. (in Polish)

BRUD S. 2001. Objaśnienia do arkusza Bielsk Podlaski Szczegółowej mapy geologicznej Polski w skali 1:50 000. Centr. Arch. Geol. Państw. Inst. Geol. Warszawa. (in Polish)

BRUD S., KUPRYJANOWICZ M. 2002. Eemian Interglacial deposits at Haćki near Bielsk Podlaski: implications for the limit of the last glaciation in northeastern Poland. Geol. Quart., 46 (1): 75-80.

FALIŃSKI J.B. 1972. Potencjalna roślinność naturalna Wysoczyzny Bielskiej. Mater. Zakł. Fitosoc. Stos. UW Warszawa-Białowieża, 24: 1-23. (in Polish)

FALIŃSKI J.B., BER A., KOBYLIŃSKI Z., SZYMAŃSKI W., KWIATKOWSKA-FALIŃSKA A.J. 2005. Haćki. Zespół przyrodniczo-archeologiczny na Równinie Bielskiej. Wyd. Białowieska Stacja Geobotaniczna UW. pp. 144. (in Polish)

KMIECIAK M. 2001. Objaśnienia do arkusza Plutycze SMGP 1:50 000.CAG PIG, Warszawa. (in Polish)

KOBYLIŃSKI Z., SZYMAŃSKI W. 2005. Pradziejowe i wczesnośredniowieczne osadnictwo w zespole kemów w Haćkach. In: Haćki. Zespół przyrodniczo-archeologiczny na Równinie Bielskiej. Faliński J.B. et al. (eds). Wyd. Białowieska Stacja Geobotaniczna UW. pp. 43-74. (in Polish)

KONDRATIUK P. 1995. Geologia, geomorfologia i gleby wokół prehistorycznej osady w Haćkach. In: Człowiek i Środowisko.
Referaty i postery 44 Zjazdu Polskiego Towarzystwa Geograficznego, Toruń. (in Polish)

KWIATKOWSKA A.J. 1972. Analiza homogeniczności runa fitocenozy przy zastosowaniu nieparametrycznego testu serii. (Statystyczna interpretacja jednorodności i struktury fitocenozy na przykładzie świetlistej dąbrowy w Puszczy Białowieskiej). Phytocoenosis 1.1: 37-77. (in Polish)

KWIATKOWSKA A.J. 1986. Reconstruction of the old range and the present-day boundary of a Potentillo albae-Quercetum Libb. 1933 phytocoenosis in the Białowieża Primeval Forest landscape. Ekol. Pol. 34: 31-45.

KWIATKOWSKA A.J. 1993. Phytoindication analysis of temporal and spatial variation of light, trophic and moisture conditions of oak forest. Fragm. Flor. Geobot. 38: 173-182.

KWIATKOWSKA A.J. 1994a. Changes in the species richness, spatial pattern and species frequency associated with the decline of oak forest vegetation. Vegetatio 112: 171-180.

KWIATKOWSKA A.J. 1994b. Effects of species diversity frequency and spatial distribution on the species-area relationship in an oak forest stand. Ann. Bot. Fenn. 31: 1-9.

KWIATKOWSKA A.J. 1996. Zmiany presji roślinożerców jako przyczyna regresji dąbrów w Puszczy Białowieskiej. Wiad. Ekol. 42.3: 137-162. (in Polish)

KWIATKOWSKA A.J., SPALIK K., MICHALAK E., PALIŃSKA A., PANUFNIK D. 1997. Influence of the size and density of Carpinus betulus on the spatial distribution and rate of deletion of forest-floor species in thermophilous oak forest. Plant Ecol. 129: 1-10.

KWIATKOWSKA-FALIŃSKA A.J., FALIŃSKI J.B. 2005a. Murawy kserotermiczne a zróżnicowanie i zasięg stepów. In: Haćki. Zespół przyrodniczo-archeologiczny na Równinie Bielskiej. Faliński J.B. et al. (eds). Wyd. Białowieska Stacja Geobotaniczna UW. pp. 81-83. (in Polish)

KWIATKOWSKA-FALIŃSKA A.J., FALIŃSKI J.B. 2005b. Zmiany struktury ekologicznej murawy w Haćkach w toku sukcesji wtórnej po zaprzestaniu wypasu. In: Haćki. Zespół przyrodniczo-archeologiczny na Równinie Bielskiej. Faliński J.B. et al. (eds). Wyd. Białowieska Stacja Geobotaniczna UW. pp. 107-114. (in Polish)

KWIATKOWSKA-FALIŃSKA A.J., FALIŃSKI J.B. 2005c. Anemone sylvestris na pagórkach kemowych w Haćkach. In: Haćki. Zespół przyrodniczo-archeologiczny na Równinie Bielskiej. Faliński J.B. et al. (eds). Wyd. Białowieska Stacja Geobotaniczna UW. pp. 115-120. (in Polish)

MATUSZKIEWICZ W. 2001. Przewodnik do oznaczania zbiorowisk roślinnych Polski. Vademecum Geobotanicum 3: 1-537. Wydawnictwo Naukowe Państwowe Wydawnictwo Naukowe, Warszawa. (in Polish)

MOJSKI. E., NOWICKI A.J. 1961. Kemy okolic Bielska Podlaskiego. Kwart. Geol. 5.4. (in Polish)

MOJSKI. E., NOWICKI A.J. 1964. Remarks on the geology of the Quanternary of northeastern Poland. Abstracts of papers VI Congress INQUA, Warszawa

OLSZEWSKA B., JUGOWIEC-NAZARKIEWICZ M. 2000. Wyniki badań mikropaleontologicznych wykonanych dla arkusza Bielsk Podlaski SMGP 1:50 000. Centr. Arch. Geol. Państw. Geol. Warszawa. (in Polish)

PIĘKOŚ-MIRKOWA H., MIREK Z. 2003. Atlas roślin chronionych. "Multico". Warszawa.

ZAJĄC A., ZAJĄC M. (eds) 2001. Atlas rozmieszczenia roślin naczyniowych w Polsce. Pracownia Chorologii Komputerowej Instytutu Botaniki Uniwersytetu Jagiellońskiego, Kraków. (in Polish) 